\title{
PME Learning Model : The Conceptual Theoretical Study Of Metacognition Learning In Mathematics Problem Solving Based On Constructivism
}

\author{
Ihdi Amin ${ }^{a}$ and Scolastika Mariani ${ }^{b}$
}

aSemarang State University, Semarang, INDONESIA bSemarang State University, Semarang, INDONESIA

Learning mathematics until today still left a lot of records that had to be improved, including passive learning, low ability of learners in problem-solving activities, the rarity of authentic assessment, emphasizing only on cognition, and others. This was a study of the literatures concerning the teaching of metacognition in mathematical problem solving. The PME learning model was a modified theory of Darling-Hammond (2003), which was a theoretical-conceptual product that offered the strategies to improve the ability of metacognition in problem solving. This metacognition strategies implemented through metacognitive activities, ie : planning, monitoring, and evaluating (PME). On PME learning model: (1) the activity planning, monitoring, evaluating explicitly raised in the core activities of learning and mathematical problem-solving activities; (2) the learning process recommended using social constructivist teaching in small groups; (3) placing the role and duties of teachers as counselors, classroom manager, motivator, facilitator, and evaluator; (4) The support system for the effectiveness of PME learning model were: Lesson Plan (LP) and Worksheet for students (WS); and (5) the direct effect was expected increasing of the metacognition ability, and the nurturant effect was expected to increase in problem solving performance.

KEYWORDS

Metacognition strategies, constructivist teaching, mathematical problem solving
ARTICLE HISTORY

Received 22 February 2017

Revised 5 May 2017

Accepted 1 Jun 2017

\section{Introduction}

Mathematics learning should not just lead learners could complete a task, where they related to problems and new ideas, but also an attempt to keep the learners' response to always be involved in the learning process (Hserbst, 2006:

\section{CORRESPONDENCE Ihdi Aminih $\square$ dimathsma@yahoo.com}

(c) 2017Ihdi Amin \& Scolastika Mariani.

Open Access terms of the Creative Commons Attribution 4.0 International License apply. The license permits unrestricted use, distribution, and reproduction in any medium, on the condition that users give exact credit to the original author(s) and the source, provide a link to the Creative Commons license, and indicate if they made any changes. (http://creativecommons.org/licenses/by/4.0/) 
317). According Maccini \& Gagnon (2002: 1), traditional education focused on operational calculations rather than on activities of thinking and problem solving, contrary with a new approach that puts greater emphasis on conceptual knowledge. However, in the conceptual knowledge, the focus was on understanding. (Baki, A., 1997). The new approach focused on conceptual learning and problem solving, using the scientific method and being the basis for mathematical activities in school mathematics curriculum developed (NCTM, 2000). Hudojo (2005: 20) argued that the mathematical learning process should involved actively learners' mental (such as motivation and awareness) even though these mental activities were very hard to see and be observed unless the learning activities followed by physical activities. Therefore, in the study of mathematics required the appropriate selection of strategies to the character of the material and the students.

Many problems in mathematics education, which until now became the records of the experts. Schraw \& Moshman (1995) stated that the learning mathematics more passive than active learning (traditional learning), causing the structure of knowledge was not developed. Kaur (2014) stated that in the learning of mathematics, students often experience difficulties to perform problem-solving activities, even smart students also experience them (Yevdokimov, 2008: 1). The difficulties occured because: (1) a lack of understanding of the problem; (2) lack of knowledge of the strategy; and (3) the inability to translate problems into mathematical model. According Verschaffel et al (in Kramarski, et al, 2002) difficulties in mathematical learning were complex. Difficulties occured at all stages of the solution process, from the first stage (about understanding what the problem was), the planning of solution process and choosing the right strategy, and the stage of deciding whether it made sense or not.Another thing that happened in mathematics was very infrequent giving authentic tasks. Kramarski, et al (2002) revealed that authentic tasks were rarely presented in a math class, so there were few who know how to improve the ability of learners completing these tasks. Instead the default tasks that were commonly used by teachers, which were tasks that only described the situation simplified, involved some quantitative information, and that there were ready-made algorithms that should be applied in solving specific problems. In terms of the development of metacognition, Carr, et al. (1994) stated that learning more emphasized on cognition, not on metacognition knowledge, but knowledge of metacognition was very important role in students' academic achievement.Metacognition was often regarded as a high-level thinking was useful for students to achieve a higher level of competence. Students who were incapable of thinking metacognition would face a mathematics as a drill or a practice exercises. (Ngan Hoe, et.al, 2001) So it was not surprising that they always say that mathematics was difficult, moreover to apply it. It was important for students to "be aware" of the strengths and limitations of their minds. The last years metacognitionhave get attentionsfrom cognitive psychology. Special attention has been focused on the interaction of metacognition and cognition in affecting of problemsolving performance. (Aurah, et.al, 2011; Havenga, et.al, 2013; Toit \& Toit, 2013)

The above description showed the need to look for solutions in the learning activities that can make learners active, improve the ability of metacognition and problem solving, improving positive attitudes toward mathematics. This 
paper offers a conceptualtheoretical products to implement strategy of metacognition in problem solving math learning in the form of PME (Planning, Monitoring and Evaluating) based constructivist. Definition of metacognition strategies in this article refered to the Ghasempour's(et al.) theory (2013) which stated that the strategy of metacognition was a regular process that was used to control cognitive activities to ensure that the objectives were reachedthrough the cognitive activities of regulating and supervising learning. The process in metacognition strategy consists of planning, monitoring the cognitive activities, and examine the results of these activities. The metacognition situation enables students to become successful learners (associated with intelligence and highlevel thinking skills) which involves active control over the cognitive processes in learning.

\section{Metacognition Teaching Strategies}

Metacognition also concerned with knowing how to reflect, to make conclusions on the analysis, and to apply in practice. In other words, metacognition also how to have cognitive tasks were important as remembering, learning, and problem solving. (Downing, 2009). In view of Schneider \& Lockl (2002), metacognition was executive abilities that involve monitoring and control. Kuhn \& Dean (2004) explains, metacognition caused learners who have been taught with a certain strategy and in the context of particular problems would be able to obtain and use a new strategy for the same context.Metacognition has three functions, namely awareness, assessment, and setting his own mind. According Meichenbaum metacognition offering one's consciousness on his knowledge and ability to understand, control, and manipulate the cognitive process himself (TEAL, 2012). Metacognition allowed one to control, manage or direct the activities through self-regulation and coercion during the study and in different situations (Okoza \& Aluede, 2013). According Ghasempour, et al. (2013), the process of cognition was inherent in every metacognitionactivity and can be present in a variety of cognitive activities. Specifically on problem-solving activities, metacognition process greatly affected theproblem solving performance. Davidson et al (in Hoe, et al, 2001) reported that there were four metacognitive processes that contribute importantly to solve the problems in various domainsie: (1) identifing and defining the problem; (2) presenting mentally a problem; (3) planning how to proceed; and (4) evaluating what was known about his performance.

Metacognition contributed very important in the success of learning, so teachers should help learners develop their metacognition ability. TEAL (2012) argued that teachers were required to encourage learners become better thinkers, to help them focus on their ways of processing information.Selfquestion, reflecting journal article, and discussing their thinking processes with others were some teachers' ways that could encourage the learners to test and develop their metacognitive processes.In mathematics learning, according Toit (2009), the use of metacognitive strategies to solve the problem, especially in helping to improve thestudents' attitude towards mathematics. Ghasempour et al. (2013) recommended to encourage students to develop metacognitive strategies in learning framework constructivism. One strategy that could be used was by self-question in a particular subject and it was more difficult than teaching procedures established for the specific situation (Gartmann and Freiberg, 1993). Ku\& Ho (2010) recommended the use of metacognitive 
strategies through metacognitive activities, ie planning, monitoring, and evaluating. Planning activities directed towards the preparation of the completion of the task and the thinking process. Monitoring activity was an activity on the process of checking and validation thoroughly on tasks. Evaluating activity was characterized by self-assessment strategies in a reasoning, thinking product and tasks progress.Jacob and Paris (in Schraw \& Moshman, 1995) stated that there were three essential skills in metacognition activity, ie planning, monitoring, and evaluation. Planning meant choosing the right strategies and provided resources that impacted performance. Monitoring respected to the ability of self-awareness on the overall oftasks performance.Evaluation regarded to assess products and to regulate the learning process., such as re-evaluate one's objectives and conclusions.

According to Fogarty (TEAL, 2012), the teaching of metacognition reached three distinct phases (PME), namely: (1) developing a plan ("Plan") before approaching the task of learning; (2) monitoring comprehension ("Monitoring") in using a "fix-up" when there was a failure of understanding; and (3) evaluating ("Evaluating") their thoughts after completing the tasks. Ann Brown et al (in Darling-Hammond et al, 2003) described the threeways directed at teaching metacognition, namely: (1) planning approaches to the tasks, including identifying problems, selecting strategies, organizing thoughts and predicting the outcomes; (2) monitoring the activities during learning through testing , revising, and evaluating the effectiveness of the strategies used; and (3) checking the results, through reevaluatiing the results by specific criteria in efficiency and effectiveness.

Definition of planning according to Arifin (2010: 2) summarized from seven experts (Joseph Enoch, Beeby, CE, Guruge (1972), Albert Waterson (Don Adam 1975): Coombs (1982): Dror Y. (1975) that the concept of educational planning were: (1) a formulation of the draft activities set based on the vision, mission and educational purposes; (2) containing steps or procedures in the process of activities to achieve educational purposes; (3) a control meant controlling the behavior of education units ( principals, teachers, staffs, students, school committees); (4) containing the formulation of the results to be achieved in the process of educational services to students; and (5) concerning the future of the development process and the education development in a given time, more qualified. According Shrawder (2006), some activities may be carried out in the framework of preparatory activities, were: (1) forming a positive attitude of students about successful learning and learning outcomes; (2) establishing and maintaining creativity or manage the mind; (3) writing learning objectives and reviewing before any learning session; (4) building confidence before starting the study; and (5) maintaining a maximum level of self-motivation.While Kramarski, et al (2002) stated, the key of metacognition learning was students worked in small groups to formulate and answer a series of questions metacognition. These questions focus on: (a) understand the problem (for example, "What was the problem and why?"); (B) establishing a link between prior knowledge and new (eg, "What were the similarities / differences between the problems faced and the problems you've solved in the past and why?"; (C) using appropriate strategies to solve problems (eg, "What right strategies / tactics / principles were selected to solve the problem and why?"; 
and in some studies also (d) reflecting the processes and solutions (eg, "What have I done wrong?"; "What was the solution made sense?" ).

The results of the Downing's study (2009) stated that there was a significant relationship between academic achievement and metacognition situation changes, and there was a significant difference in learning ability and development of metacognition. Therefore, it was important to expose students in metacognition situation to further implement cognitive resources through control of metacognition (Ghasempour et al., 2013). The ability of metacognition helpedstudents to improve their problem solving skills and in general their academic achievement. (Aurah, et.al, 2011: 1). Metacognition scaffolding facilitated students in designing of the problrm solving process by helping them achieve their goals and deadlines, were involved in the process, organizing ideas and thoughts, justifying misconceptions, revising plans and strategies those were not effective, avoiding delays, using time effectively, monitoring and evaluating their progress. (Jo An and Li Cao, 2014: 565). Through the metacognition learning students were more successful, had more positive attitude, developed the ability to understand the problems, learning to plan solutions, developing the reflective thinking skills, controling and aware of the process, developing the experimental designs, as a bridge between teories and practices, students were also more active in the classroom. (Sahin and Kendir, 2013: 1790). Darling-Hammond et al (2003) stated that metacognitive strategies helped the students become more efficient and powerful in their learning because they helpedthem to find information, evaluate when they need additional resources, and understand when to apply different approaches to problems.

Schraw \& Dennision (1994: 2) recommended a metacognition teaching through the following strategies: (1) monitoring the understanding of metacognition, carried out through reading, identifying the components, and setting goals for themselves and planing the steps to achieve these goals; (2) controlling the error, reviewing the activities carried out through every step to see if there were mistakes made, reading the back issues from time to time to check out the important parts are forgotten, and making changes if experiencing confusion; and (3) revising, conducted through figuring out how to check to see if the solution is correct, reviewing all that has been done to make sure not to forget anything, and re-read the job description and reflect. Ku\& Ho (2010) conducted a study on the use of metacognitive strategies for thinking using think aloud, with a focus on comparing the use of the learners' strategies with different levels on critical thinking skills.To measure the effectiveness of metacognition strategiesimplementation, according to Darling-Hammond (2003) could be used ten strategies that illustrated the process of reflection on learning and taught regulations or directed one's work, namely: (1) predicting outcomes, meaning learners make predictions towards the solution of problems encountered; (2) Evaluating work, meaninglearners reviewed their work and determined where the challenges and weaknesses of their work and thought; (3) Questioning by the teacher, related to the teacher's questions when learners work; (4) self-assessing, meaninglearners reflect on their learning and determined how well they had learned something or how their abilities have been developed; (5) self-questioning, meaningstudents used questions to check their own knowledge when they were learning; (6) selecting strategies, 
meaninglearners decided which strategy was used to complete the task; (7) using directed or selective thinking, meaning learners consciously choose to follow a particular line in the structure of thinking and approach in order to find an answer; (8) using discourse, meaning learners menduskusikan their ideas with friends or teachers; (9) critiquing, meaning learners to provide feedback to others about their work in a constructive manner; and (10) revising, meaninglearners bring back their jobs after receiving feedback, the opportunity was used learners to renew their thoughts and check their use of learning strategies.

\section{Constructivism Approach}

Constructivism was rooted in the assumption that knowledge was formed in the human brain, and the subject was thinking of going to construct what he knew by his own experience, knowledge could not be regarded as a copy of external reality, and truth claims could not be based on claims about reality. (Patrick, 2013: 1). So as to verify that person's knowledge was correct, or that what one knew was true, that person needs to see reality meant "else" other than the person's knowledge. The importance of this skeptical attitude for mathematics educators was to remind them that the students have their own mathematical reality that teachers and researchers could understand only through the models from them. (Steffe et al, 1988; Steffe, Glasersfeld, et al 1983).

So all knowledge were subjective (Muijs\& Reynolds, 2008: 96). Constructivism was not a single viewpoint, at least this understanding hasthree different perception: (1) exogenous constructivism, stating that the acquisition of knowledge represented a re-construction of the outside world; (2) endogenous constructivism, stating that the knowledge gained from the knowledge that has been studied before, not directly from the interaction with the environment; and (3) dialectical constructivism, which stated that the knowledge gained from interactions between people and their environments, but the constructions were not always tied to the outside world or the overall activities of the mind (Schunk, 2012: 325)

In a constructivist approach, the learner was assumed to build conceptual understanding themselves as participating in cultural practices through a number of interacting with others (Cobb, et al, 1996: 8) . Constructivist teaching principles had a number of consequences, i.e.: (1) learning was always an active process; (2) the best learning was by completing various cognitive conflicts through experiences, reflections, and metacognitions; (3) learning was the search for meaning which required big ideas and explorations; (4) construction of knowledge could be done individually or collectively (social constructivist); (5) learning should always be conceptualized, which means learning should be linked explicitly to prior knowledge; and (6) teaching meant empowering learners and enabling learners discovered and reflected on the realistic experiences (Muijs\& Reynolds, 2008: 97-99).

\section{Problem Solving Teaching and Learning}

Problem solving was defined as an attempt to achieve some outcomes, when there was no known method (individuals strived to achieve results) to achieve them. That meant just the complexity or difficulty could not be cited as a 
problem (Schoenfeld, 1992). Problem-solving activities more emphasized to engage in mathematical activities, for example, building a model, representation, establishing patterns of inference (Lester, 2013). The emergence of the ability to solve problems caused by previous experience factor, created by environmental factors and not made by mental machines (Feist\&Feist, 2013: 182). Learners became better in solving problems when given exercises. Learners were encouraged to solve the problems more than just finding a solution (Gartmann\& Freiberg, 1993) .Therefore, the problem solving performance was strongly supported by previous experiences through exercises, reading a book, listening to the advice of experts, and others.

Problem solving was a major part of mathematics that had many applications and often these applications were critical issues in mathematics (Ali, et al., 2010). According to Carlson \& Bloom (2005), a mathematics assignment was a problem if: (i) challenging (required basic mathematical concepts and knowledge that can be accessed by any mathematician, irrespective of the field of specialization); (ii) the character of the problem would produce a variety of pathways solution, thus giving rise to a variety of cognitive and metacognition behaviors, also prolonged engagement during the solution process; and (iii) a fairly complex problem led to stop and gain a strong affective responses. Stanic and Kilpatrick (in Schoenfeld, 1992) identified three major themes about the use of problem-solving, i.e.: (1) solving the problem as a context, which meant solving the problem used as a vehicle for curricular goals; (2) as a problem-solving skills, assumed that reasoning learning skills in such domains as mathematics would result improved performance in general reasoning in other regions; and (3) the problem solvingas an art, in this view the problem-solving was the heart of mathematics, if not the mathematics itself.

In each problem-solving activities, according to Polya (Carlson \& Bloom, 2005), there were four phases of the process of solving the problem as a linear progression from one phase to the next phase, namely: (i) understanding the problem; (Ii) developing the plan; (Iii) implementing the plan; and (iv) looking back. While Carlson and Bloom developed problem-solving framework further called Multidimensional Problem Solving Framework (MPS-F). MPS-F was aproblem solvingcharacterized attribute, also had four phases traversed in solving mathematical problems, namely (1) orienting phase, marked by an intense effort to understand the information in question; (2) planning phase, marked by an attempt to access the conceptual knowledge and heuristics as a tool to build suppositions and strategies ; (3) executing phase, marked by an attempt to access their conceptual knowledge, facts and algorithms when building statements and doing calculations; and (4) checking phase, characterized by verifying the reasonableness of their results and the correctness of their calculations, and reflecting the quality of the process (Carlson \& Bloom, 2005; Voskoglou, 2008).

Lester (2013) stated that problem solvingteaching colud be developed through the principles, i.e. :

a. The principle of aprolonged involvement. Learners should be involved regularly in the work on the problem-solving tasks, over long time periods. 
b. The principle of a variety of tasks. Learners were given the opportunity to solve a variety of problematical tasks.

c. The principle of complexity, the problem solving performance capability was best developed when it occured in the context of essential math concepts learning.)

d. The principle of systematic organization. Teaching problem solving and metacognition in particular, was most effective when taught systematically organized under the direction of teachers.

e. The double principle for the role of the teacher. Problem solving teaching that emphasized metacognition skills development should involved teachers in three different roles, but related one another : (a) as an external monitor, (b) facilitating learners' metacognitive awareness, and (c) as a model of finesse in metacognition-problrm solving.

f. The principle of group interaction. The default setting for classroom learning activities for students to work in small groups (usually groups of three or four persons).

g. Principle of assessment. Teacher lesson plan should include attention to how learners' performance would be assessed.

Presenting a problem to the students meant giving them the opportunity to learn to take risks, to adopt a new understanding, to apply the knowledge, to work in context and enjoy the sensation of being the discoverer (Ali et al., 2010). Schoenfeld (in Toit, 2009) considered that solving the problem meant promoting self-regulation. Problem-solving activities provided the ideal opportunity to improve metacognition strategies and learners who had the metacognition ability would be superior in problem solving. The problem-solving performance capabilities was closely related to the ability of metacognition. Several studies had concluded that the process of metacognition could improve problem solving performance. Lin (in Yimer and Ellerton., 2006) stated that the function of learner's internal metacognition provided the key to successful learning in a learners' control situation. The Inability to monitor accurately, to reflect, to evaluate, and to adjust the learning would impede learning process and was an indication that the student had poor metacognition abilities. Gartmann and Freiberg (2012) in his research revealed that some learners, when they were writing comments on the problem solving tasks, able to see / find approaches alternatives and further they would use them as a correction (self regulation) if they solve the task again. Meanwhile, according to Hoe, et al (2001), problem solving as an active process which tried to change the state of the initial problem into the desired one, and metacognition helped the problem solver for : (1) recognizing that there were problems to be solved, (2) finding out what the problem was, and (3) understanding the problems to reach a solution. The above explanation reinforced the statement about the linkages between metacognition abilities and problem-solving performance.

\section{PME (Planning, Monitoring and Evaluating) Learning Model}

A learning model was a representation of a learning environment, which included all the behavior of all the parts involved in learning, when the model was applied (Joyce et al, 2009: 30). So in the learning model was obtained a description of the behaviors of learners, teacher's behaviors and learning scenarios that occured. The application of a learning model would greatly affect the ability of students to be powerful learners powerful. A successful learning 
was learning which was able to engage learners in tasks that were loaded with social and cognitive charges, and teach them how to do these tasks productively (Joyce et al, 2009: 7). Therefore, the success of the learning not only of how much students achieve a certain competence, but also how much the teachers were able to improve the ability of learners to learn.

PME learning model which was developed in this study described a learning environment, included all the behavior of all parts involved in learning, proceed regularly, used to control cognitive activities and to ensure that the ability of metacognition can be fulfilled. PME learning model was a concept that was modified from the concept of metacognition strategies and mathematical problem-solving that had been researched and presented by experts before. PME learning model was the concept of learning model that emphasized these activities, i.e. : planning, monitoring, and evaluating as primary phases of the learning activities and the operational steps in problem-solving activities. The learning model aimed to make the learning process in order to create active learners, can improve problem-solving abilities of learners, can increase positive attitudes of learners, and can increase the ability of learners' metacognition. While the direction of the development of the model, according to Joyce et al (2009) include (1) the structure of the model, (2) the social system, (3) the role / tasks of teachers, (4) the support system, and (5) the impact of instructional and companion.

\section{The Structure of PME Learning Model}

The structure of PME learning model was done by creating a lesson plan (LP) nuanced of planning, monitoring, and evaluating and equipped with worksheet for students (WS). According to Uno (2009), the learning plan was a set of writings contained learning and/or lab activities plan had to be prepared by the teacher. The lesson plan was needed to improve learning. Efforts to improve the learning was done with the assumption that: (1) to improve the quality of learning should begin with planning embodied in the form of instructional design; (2) to design learning was needed system approach; (3) the learning design refered to how people learn; (4) planning a design refered to learners individually ; (5) learning led to the achievement of learning objectives (direct and accompanist); and (6) the ultimate objective of learning design was to facilitate the students to learn. LP helped to ensure that the learning process in line with the objectives of the curriculum and the learning objectives (Duncan \& Met, 2010), and LP could characterize the professionalism of teachers (Jone, 1998). While WS can be used as a means for students to acquire and demonstrate an understanding on the topic.

Shrawder (2006) stated, a good lesson plan helped complete important tasks on the setting of purposes and describe how teachers would reach them. Lesson plan was a map or framework used for planning and directing each classroom from the first meeting until the final exam. Lesson plan ensured teachers had the logical creations, the essence of a systematic learning process to make certainty learning achievement of learners in order to learn more in the future.

LP of PME learning model contained learning activities were divided into three stages, namely the preparation/ introduction stage, the the core stage, andand the closing stage. Core activities on PME learning model is designed to 
have three phases, namely phase 1 or planning phase, phase 2 or phase monitoring phase and phase 3 or evaluating phase. In the phase of evaluating which contained a mathematical problem-solving activities also proceed through three steps : planning, monitoring, and evaluating. So the PME activities (planning, monitoring, evaluating) explicitly raised in the core activities of learning and math problem-solving activities. The following descriptions explained each the learning stage activities.

\section{Stage I : Preparatory / Introduction Activities (Start)}

This stage was referred to as preparation activities for the primary purpose at this stage was to prepare the means of learning and learners so that the learning process could run well and achieved the expected goals. In the context of constructivist teaching, this phase was the introductory phase (start) because in this phase the teacher might want to start by measuring the initial knowledge or the prerequisite knowledge possessed learners and defining the various activities. Through the introduction activities, it was expected that learners could more easily connect the knowledge that they already had with the knowledge to be learned. Duncan \& Met (2010) stated, when designing instruction, the teachers must consider the position of learners' understanding now and how learners required that topic (whether the topic which was needed learners workable them or not).

Preparation stage includes three activities :First, learning conditioning activities and preparing the means of learning. The scope contained conditioning activities to the learners and setting up the learning infrastructure required. Activities included in the conditioning of learners i.e : checking the attendance of students, splitting the students into groups (if required group learning), arranging seating students, and setting / agreeding learning model that would be used. While learning tool preparation activities including setting up the media of learning, preparing learning resources, setting up assessment instrument, and explained the learning the learning objectives to be achieved. Second, mental preparation activities of learners in learning. The scope contained the mental preparation activities of learners so that they were expected to have high motivation in all learning activities. The activities carried out in the form of: (a) attempting to build the students' positive attitude about the learning success and learning outcomes; (b) attempting to establish and maintain students' creativity ormanagement of thinking; (c) attempting to build self confidence before starting the learning; and (d) attempting to maintain the peak level of self-motivation. Third, measuring the students' prior or prerequisite knowledge activities. The scope provided the prerequisite or prior knowledge detection activities that had been owned by the students as the initial provision to participate in learning activities. Begining with identifying the prerequisite/previous knowledge followed by checking (monitoring) and assessment (evaluating) the ability of learners. Checking and evaluation could be done through a question and answer (establishing communication) or giving a little exam (quiz) to help the students recalled the prerequisite knowledge or previous topic. Muijs\& Reynolds (2008) provided alternative introduction activities through a problem that was relevant to everyday life and in accordance with the topic given. 


\section{Stage II: The Core Activities (Exploration, Reflection, Application and Discussion)}

This stage was referred to as a core activity for the main purpose of this stage was to give a new topic / material according to the learning objectives set. Through this core activity was expected learners gained optimally additions and understanding of the topic / new material. In this core activity, the learning process was also divided into three phases, namely the planning, monitoring and evaluating phases.

\section{Phase 1: Planning}

This phase contained the preparation activities and the transfer of new knowledge (topics). In this phase, doing a process of exploration and elaboration on new topics related to the learning objectives set. In order to the exploration process could run well, learners were encouraged to interact actively with the environment and seriously observe a variety of symptoms and objects. In this exploration learners was expected to get an overview about new topics, and become familiar with the new topic (gain basic understanding). Furthermore a basic understanding gained by learners need to be deepened through the activities of elaboration, i.e. the effort to cultivate diligently and carefully knowledge gained from exploration activities. Activities done in the process of elaboration, among others: (a) learners read and wrote the results of exploration; (B) learners discussed to learn more about something; (c) learners analyzed the strengths or weaknesses of arguments; and (d) learners built consensus through a cooperative and collaborative activities, prepared reports or writings, and presented the learning results or demonstrated a procedure (presentation). In this elaboration learners were expected to gain a fuller and in-depth understanding about new topics.

In order to the learning activities in the planning phase could run optimally, exploration and elaboration needed to notice the main elements of effective direct teaching, namely: (a) teaching structured clearly, (b) the structured presentation and taught clearly adapted to the students' abilities; (c) pacing, which meant that regulating the speed step in teaching the subject matter; (d) modeling which demonstrated a procedure to students; and (e) to conduct an interview and an interactive discussions. On the other hand, according Muijs\& Reynolds (2008), this part of learning should involved real situations or materials, as well as provided opportunities for group work. The activities should be structured such that students faced issues that enable them to develop an understanding and quite challenging.

\section{Phase 2: Monitoring}

This phase contained the checking activities towards understanding new topic outcomes of exploration and elaboration. Monitoring could be done through the reflection, that looking back action that has taken, then analyzed and discussed what had been done. The monitoring activities of the new understanding of the topic was done through the provision of problem-solving task in which problem-solving activities directed to be implemented in three problem solving phases namely planning, monitoring, and evaluating. The teacher gave mathematics problem-solvings through Worksheet for students 
(WS) that had been prepared previously. Learners were required to work or conduct problem-solving activities.

During problem-solving activities, teachers sought to provide assistance process (scaffolding) at learners who needed it and conducted a review of the work produced by learners. Expected to be able to awaken constructivist shades, namely : (1) the process of scaffolding that giving an assistance to learners to achieve tasks that could not be controlled by him own, then gradually withdraw their support; (2) the coaching process, i.e. the process of motivating the students, analyzed their performance and provide feedback on their performance; (3) articulation, which encouraged learners to articulate ideas, thoughts, and their solutions; (4) reflection, which compared the obtained solution the students with the solution of the "experts" or othered learners at the same time thinking about how to solve the problem, the strategy used, and assess the effectiveness of the strategy; (5) collaboration, which emphasized the learners about how to learn from others; (6) exploratory and problem-solving activities, ie activities gained knowledge or information as possible from sources around him which was then used to solve the problem. Similarly during problem-solving activities, students were encouraged to do three metacognition learning strategies: (1) monitoring the activities of understanding metacognition, which included self-assessing, self-question, predict outcomes, and selecting a strategy; (2) the error control activities, including the use of lead or selective thinking and the use of discourse; and (3) revising activities, covering activity of critiquing and revising.

\section{Phase 3: Evaluating}

This phase contained an assessment of the activity of thinking and understanding related to knowledge / new topic. The scope of the evaluation activities undertaken was a self-assessment activities on a reasoning, thinking product and task progress, as well as an evaluation that led to the metacognition abilities improvement of learners. In this case, the learners are encouraged to do three activities: (1) present the results of activities and explain the entire problem-solving activities; (2) taking into account input from other groups or teachers, as well as analyze the strength or weakness of the arguments that have built; and (3) revising through cooperative and collaborative activities if found weaknesses in the argument. This was in line with the opinion of Muijs\& Reynolds (2008) which stated that there were good teachers always remind learners of metacognitive processes applied in resolving the problem. Once the evaluation was completed, the teacher gave learners the opportunity to present the settlement of problems obtaining and asked other learners to criticize or give inputs. If possible the students were also asked to analyze and comment to the metacognitive activities, i.e. planning monitoring, and evaluating has done.

\section{Stages III: Closing Activities}

This stage was called the closing activity for the main purpose of this stage was to close the learning, knowing achievement of learning objectives, confirming the new topic that has been built, and making efforts to the next learning conditioning. Confirmation process aimed to provide confirmation of the knowledge / new topics that could be done in several ways, among others : providing feedback on what was produced learners, provide an appreciation of the strengths and weaknesses of learning outcomes, giving an appreciation of 
the strengths and weaknesses of learning outcomes, providing additional information, encouraging students to use the knowledge further, asking students working on other tasks to create a concrete and contextual learning product. Through the closing activities were expected that learners gained a better understanding more about the new topic or material. While conditioning for subsequent learning was done through the provision of structured tasks related to the next topic. In this case the learners were given the task to carry out initial exploration on the next topic to be studied. With the provision of structured tasks, learners were expected to have the basis for the next step on the topic, so that the following learning activities could be run well and involved the interaction of students better.

\section{The Social Systems of PME Learning Model}

Social system with regard to interactions between teachers, learners, learning resources, and instructional media used. On the PME learning model, the learning process was recommended to use social constructivist teaching in small groups. This was in line with the opinion of Kramarski, Mevarech, \&Arami (2002) which stated that metacognitive teaching strategies recommended to prepare the students in small groups to formulate and answer a series of questions metacognition.

Nuance of constructivist teaching could be found in the elements of PME learning model, as follows:

a. In the first stage (preparatory activities / introduction) did the coaching process, i.e. the process of motivating the students, analyzing their performance and providing feedback about their performance, which was part of the mental preparation activities of learners in the learning.

b. In the second stage (core activities) or planning phase carried out exploratory activities, i.e. activities which gained the knowledge or information as possible from sources around him; and collaboration, which emphasized the learners about how to learn from others.

c. In the second stage (core activities) or the monitoring phase of reflection, the students were encouraged to check the understanding that they get from the exploration and elaboration to look at their advantages and disadvantages.

d. In the second stage (core activities) the evaluating phase was done some process that showed shades of constructivist, namely: the scaffolding process that gave assistance to learners to achieve tasks that could not be controlled by their own, then gradually withdraw their support; articulation process that encouraged learners to articulate ideas, thoughts, and their solutions; reflection process to assess the effectiveness of the strategy; collaboration with others; explorative activities were used to support the resolution..

e. In the third phase (the closing) was given the structured task to encourage learners performed exploratory activities, i.e. activities gained knowledge or information as possible on the next material.

f.Teachers who have the flexibility and adaptability, the teacher could respond and react to the ideas of learners.

\section{The Roles and Tasks of the Teachers}


Roles / duties of the teachers with regard to the attitudes, duties, and functions of the teacher in the learning process, among others :Rusman (2013) argued, the teachers were the dominant factor in education because teachers played an important role in learning, and learning was an important element in the overall education. PME learning model was a model that put the roles and duties of teachers as counselors, classroom managers, motivators, facilitators, and evaluators. Roles as mentors could be seen in the activities of teachers: (1) Guiding learners found and recaptured the topic prerequisite or recalled the topic / previous material; (2) guiding learners to complete the task; (3) guiding the students understood and mastered the new topic / material; and (4) guiding learners made conclusions of the topic.

Role as a manager of a class could be seen in the activities of teachers conditioning learners in early learning activities and made the learning process in which little by little learners invited to reduce dependence on the teacher. PME instructional model which was developed from metacognition learning strategies, was essentially a learning model that aimed to improve the ability of metacognitive learners i.e. the ability to reflect on what had been thought and the ability to self-control of the action they had taken. Rusman (2013) stated that one of the good classroom management was to provide opportunities for learners to gradually reduce dependence on the teacher, so that learners were able to guide their own activities. Gradually learners should learn self-control and self-activity. A facilitating role could be seen in the activities of teachers made contact with learners to gain a higher understanding. This role appeared on the scaffolding process when teachers facilitated the learners by providing assistance to learners to achieve tasks that could not be controlled by their own, then gradually withdrew his support. By providing scaffolds, teachers have helped students gained the knowledge to a higher level in the zone of proximal development.

Role as a motivator could be seen in the activities of teachers asking students to work and asking questions that motivated learners to work. PME leraning model emphasized on learning activities that encouraged learners had an understanding and a better awareness about the thinking process theirselves. These activities were reflected in: (1) encouraged students to work; (2) encouraged students to do self-question and self-assessing; and (3) encouraged students to tell their thoughts with verbal language (think aloud). This activity was expected to encourage students to be a good learner. TEAL (2012) stated that teachers were required to encourage learners become better thinkers, helped them focus on their ways to process information through selfquestion, to reflect journal, and to discuss the thought process..

Role as evaluators could be found in the activities of teachers to give assignments or to conduct a discussion on the prerequisites topic / material or previous material; to conduct an evaluation to determine the success of learning; to evaluate for repair and reinforcement; and to provide structured assignment as a homework. Rusman (2013) stated that assessment was done to: (1) determine the level of achievement of the objectives that had been formulated; (2) determine the accuracy of the method used; (3) determine the position of the students in the class or group; and (4) feedback on the learning process to improve and enhance the learning process further. 


\section{The Support System in Learning Model PME}

Support system with regard to the other components of learning that could be used to increase the effectiveness of the learning process. In this study the components of learning designed to support the effectiveness of the learning model PME included Lesson Plan (LP) and worksheets for students (WS). According to Duncan \& Met (2010), LP or lesson planning helped to ensure that the learning process in line with the objectives of the curriculum and the learning objectives. Learning that had been well planned allowing students to become successful learners because learning was not only shaping how and what students learned, but also had an impact on students' attitudes about learning.

Jone (1998) stated that the lesson plan could be a characteristic of the professionalism of teachers. Lesson plan was the very core of the process of reflection that teachers did, the fundamental question as a reflection process with regard to what students should learn and how this would be achieved..

In general, the lesson plan contained the device and learning strategies that should always be considered when design it, namely: setting goals and learning agenda, the design of retreat, the context of the lessons learned in the unit, the strategy of research-based learning, assessment, feedback, learnerscentered learning, teaching which according to students' abilities, differentiation or noticing the difference, motivation, mentoring from teachers or peers (scaffold), developing appropriate mental practices, Bloom's taxonomy, and the closing activity (Duncan \& Met, 2010). Shape and charge of the LP developed adjusted to the rules of preparation of the LP and the curriculum set by the government or by the teacher. LP needed to be compiled in a complete and systematic manner that learning occured in an interactive, inspiring, fun, challenging, efficient, motivating the students to actively participated and provided enough space for innovation, creativity, and independence in accordance with their talents, interests, psychological and physical development of learners. LP components usually consisted of identity, which was the name of the school or education units, allocation of time, learning objectives or the indicators of competencies achievement, learning materials, teaching methods, instructional media and learning resources, learning steps, and assessment of learning outcomes.

\section{The Instructional and nurturant effects}

Every model of learning was always expected to make instructional and nurturant effects. Instructional effects were the result of learning achieved immediately after the learners learned according to the model used, as a result of the achievement of the learning atmosphere was intentionally directed to achieve the goals that have been set or agreed upon. Nurnurant effects were another learning outcomes generated by the learning activities in accordance with the model used, as a result of the achievement of learning environment was experienced directly by the learners without guidance of teacher (Rochmad, 2009). Jacob and Paris (in Schraw\&Moshman, 1995) stated, cognition arrangements regarding metacognitive activities helped to control thought or person learned, in this case there were three essential skills, namely planning, monitoring, and evaluation. Brown and Flavell (in Veenman et al, 2004) stated that the expertise in task analysis, planning, supervising, monitoring, and the recapitulation was a manifestation of metacognition skills. Me \& Ho (2010) 
conducted a study and recommended the use of metacognitive strategies through metacognitive activities, i.e. planning, monitoring, and evaluating. So activities planning, monitoring, and evaluation were the most esensial. So that metacognitive activitis in this study the direct impact was expected from the application of PME model was the increasing ability of metacognition.

Several studies have concluded that the process of metacognition improved performance of problem solving. Darling-Hammond et.al (2003) argued that metacognitive strategies could make the learning process more streamlined and efficient for learners attempted to find information, assessment, and tried to apply different approaches to a problem. Davidson et al. noted that there were two metacognition processes that contributed important to the performance of solving the problem of planning how to proceed and evaluate what you know about your performance (Hoe, et al., 2001). Schoenfeld (in Toit, 2009) argued that the problem-solving activities meant to promote self-regulation. Problemsolving activities provided the ideal opportunity to improve metacognition strategies and metacognition abilities of learners with excel better in terms of problem solving. Of the overall the above opinions could be concluded that the metacognitive processes that were implemented in the activities of planning, monitoring, and evaluation could improve problem solving performance. Because of PME learning model was a learning model that specifically implemented planning, monitoring and evaluation activities, so that the PME learning model was believed to improve the problem solving performance. In this case the nurturanteffects expected on the implementation of PME learning model was improving problem solving performance.

\section{The Closing}

From the whole descriptions above authors believed that the PME learning model could bring learning activities on the expected goals that made learners active, improved problem-solving abilities of learners, increased positive attitudes of learners, and improved the ability of learners' metacognition. This belief was based on several indicators, namely: (1) learning activities on PME learning model had been structured in sufficient detail, either in whole or activities at each of the stages and phases; (2) the process of giving material was started from reinforcement to the prerequisitesor previous materials ; (3) the core activities were designed and made possible the process of repetition (learning repetition activities and repetitive testing activities); (4) The PME learning model encouraged students to work and reflect on what they were doing; and (5) PME learning model nuanced constructivist teaching seeking the learners constructed enthusiastically their own knowledge. For further research, these conceptual ideas could be applied in the classroom and developed through research. 
The Scheme of PME Learning Model Development

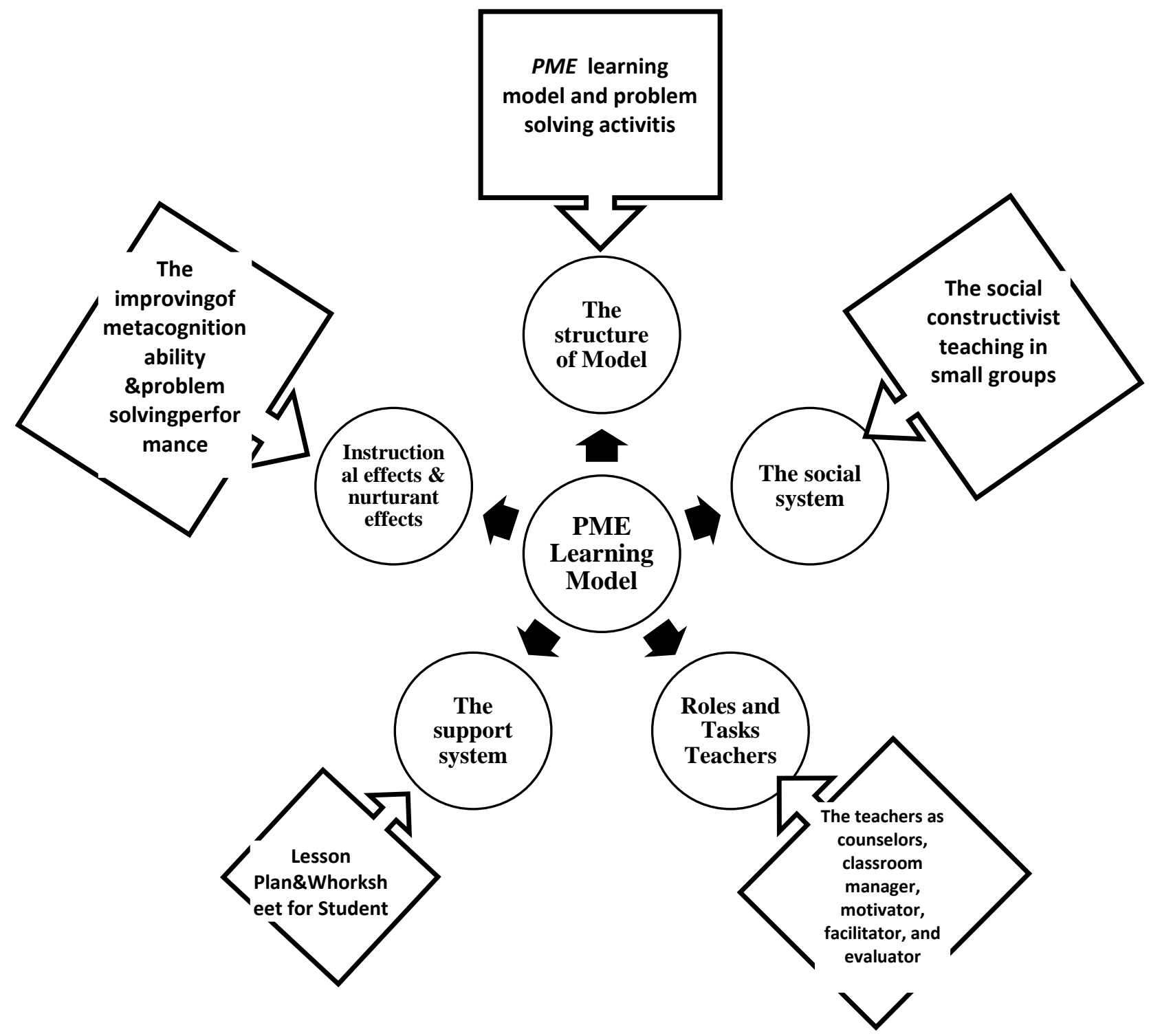

\section{Disclosure statement}

No potential conflict of interest was reported by the authors.

\section{Notes on contributors}

Ihdi Amin , Student of doctorate mathematics education study program, Semarang State University, Semarang, Indonesia ; High School Teacher and member of Teachers Union Republic of Indonesia, email : ihdimathsma@yahoo.com 
Scolastika Mariani, Doctor and Lecturer, Semarang State University, Semarang, Indonesia; member of Indonesian Mathematical Society, email: scmariani.unnes@gmail.com

\section{References}

Ali, R.,Hukamdad, Akhter, A., \& Khan, A. (2010). Effect of Using Problem Solving Method in Teaching Mathematics on the Achievement of Mathematics Students.Asian Sosial Science, 6(2), 67 - 72, Pakistan.

Arifin. 2010. Konsep Perencanaan, Pendekatan Dan Model Perencanaan Pendidikan. uploaded on July 15, 2016. https://drarifin.wordpress.com/2010/07/15/konsep-perencanaan-pendekatandan-model-perencanaan-pendidikan/

Aurah, Catherine M. ; Setlhomo Koloi-Keaikitse, Calvin Isaacs, Holmes Finch. (2011). The Role Of Metacognition In Everyday Problem Solving Among Primary Students In Kenya.Problems of education in the 21st century. Volume 30, 2011

Baki, A., (1997). Educating Mathematics Teachers. Medical Journal of Islamic Academy of Sciences, 10(3): $93-102$

Carlson, M.P. and Bloom, I. (2005). The Cyclic Nature of Problem Solving: An Emergent Multidimensional Problem-Solving (MPS) Framework. Journal: Educational Studies in Mathematics, 58(1), 45 - 75. Tersedia: http://www.jstor.org/stable/25047137.

Carr, M., Alexander, J., \& Foldes-Bennet, T. (1994).Metacognition and Mathematics Strategy Use.Applied Cognitive Psychology, 8, 583-595.

Cobb, P., Jaworski, B., \& Presmeg, N. (1996). Emergent and Sosiocultural Views of Mathematical Activity. Theory of Mathematical Learning, Lawrance Erlbaum Associates, pp. 3-19.

Darling-Hammond, L. et al, (2003).The Learning Classroom: Theory into Practice. Stanford University: Annenberg/CPB. Available :https://www.learner.org/ courses/learning classroom/support/09_metacog.pdf.

Downing K.J. (2009).Self-Efficacy And Metacognitive Development. The International Journal Of Learning. Volume 16, Number 4. Tersedia: http://Www.Learning-Journal.Com, ISSN 14479494.

Duncan, G., \& Met, M. (2010).STARTALK: From paper to practice. College Park,MD: National Foreign Language Center at the University of Maryland.Available at www.startalk.umd.edu/lesson_planning.

Feist, Jess \& Feist, Gregory J. (2013).Teori Kepribadian (Theory of Personality, $7^{\text {th }}$ ed). Jakarta: Salemba Humanika.

Gartmann, S. and Freiberg, M. (1993). Metacognition and Mathematical Problem Solving : Helping Students to Ask The Right Questions. Journal: The Mathematics Educator, 6(1), 9- 13.

Ghasempour, Z., Bakar, M.D., \& Jahanshahloo.G.R. (2013).Innovation in Teaching and Learning through Problem PosingTasks and Metacognitive Strategies.International Journal of Pedagogical Innovations, 1(1), $53-62$.

Handoko, TH. (1984). Manajemen. Yogyakarta : BPFE

Havenga, Marietjie ; Betty Breed; Elsa Mentz, Desmond Govender; Irene Govender; Frank Dignum, Virginia Dignum. (2013). Metacognitive and Problem-Solving Skills to Promote Self-Directed Learning in Computer Programming : Teachers' Experiences SA-eDUC JOURNAL Volume 10, Number 2 October 2013

Herbst, P.G. (2006). Teaching Geometry With Problems: Negotiating Instructional Situation and Mathematical Tasks. Journal for Research in Mathematics Education, 37(4), 313 - 347.

Hoe, L.N., Shook Cheong, A.C., Lee Peng Yee, L.P. (2001). The Role of Metacognition in the Learning of Mathematics among Low-Achieving Students.Teaching and Learning Journal, $22(2), 18-30$.

Hudojo, H. (1988). Mengajar Belajar Matematika. Jakarta: Departemen Pendidikan dan Kebudayaan. Dirjen Dikti. Proyek Pengembangan LPTK.

Hudojo, H. (2005). Kapita Selekta Pembelajaran Matematika. Malang: Universitas Negeri Malang. 
Jo An, Yun ; Li Cao. (2014). Examining the Effects of Metacognition Scaffolding on Students' Design Problem Solving and Metacognitive Skills in an Online Environment. MERLOT Journal of Online Learning and Teaching, 10(4), December 2014.

Jone, J. (1998). Lesson planning: Towards purposeful learning and effective teaching. Encuentro.Revista de Investigación e Innovación en la clase de idiomas, 10.

Joyce, Bruce, Weil, Marsha, \& Calhoun, Emily. (2009). Models of Teaching (Model-model Pengajaran). Yogyakarta: Pustaka Pelajar

Karpicke, J.D., Butler, A.C. \& Henry L. Roediger, H.L. (2009). Metacognitive strategies in student learning: Do students practise retrieval when they study on their own?.MEMORY, 17 (4), 471-479.

Kaur, Berinderjeet. (2014). Mathematics Education In Singapore - An Insider's Perspective. IndoMS-JME, 5(1), 1-16

Kramarski B., Mevarech, Z.R., and Arami, A. (2002).The Effects of Metacognitive Instruction on Solving Mathematical Authentic Tasks.Educational Studies in Mathematics, 49, 225-250.

Ku, Kelly Y. L. \& Ho, Irene T. (2010).Metacognitive strategies that enhance critical thinking.Journal: Metacognition Learning, 5, 251-267.

Kuhn, D. \& Dean Jr, D. (2004). Metacognition: A Bridge Between Cognitive Psychology and Educational Practice. Theory into Practice, 43(4), 268 - 273.

Lee,Ngan Hoe ; Agnes Shook Cheong Chang; Lee Peng Yee. (2001). The role of metacognition in The learning of mathematics among low-achieving students. Teaching and Learning, 22(2), 18-30.

Lester Jr, F.K. (2013).Thoughts about Research on Mathematical Problem Solving Instruction. Jorunal: The Mathematics Enthusiast (TME), 10(1) \& 2, $245-278$.

Maccini, P., \& Gagnon, J.C., (2002). Perceptions And Application Of NCTM Standarts By Special And General Education Teachers. Exceptional Children, 68, 325-344.

Muijs \&Reynolds . (2008). Effective Teaching. Yogyakarya: Rosdakarya

Okoza, J. \& Aluede, O. (2013).Understanding metacognitive awareness among teachers in the school system: issues and benefits. Inkanyiso, Journal Humanistic \& Sosial Science, 5(1).

Patrick, Thompson, W. (2013). Constructivism in Mathematics Education. In Lerman, S. (Ed.) Encyclopedia of Mathematics Education : Springer Reference (www.springerreference.com). Springer-Verlag Berlin Heidelberg. DOI: 10.1007/SpringerReference_313210 2013-05-10 00:00:07 UTC

Rusman. (2013). Model-model Pembelajaran: MengembangkanProfesionalisme Guru (Cetakan ke-6). Jakarta: PT. RajaGrafindoPersada.

Sahin, SM ; Fatma Kendir. (2013). The Effect of Using Metacognitive Strategies for solving Geometry Problems on Students' Achievement and Attitude. 2013. Educational Research and Reviews, 8(19), 1777-1792. 10 October 2013. DOI : 10.5897/ ERR2013.1578. ISSN 1990-3839 (C) 2013 Academic Journals. http://www.academicjournals.org/ERR

Schneider, W. \&Lockl, K. (2002). The Development of Metacognitive Knowledge in Children and Adolescents. In Perfect, T. and Schwartz, B. (Eds.), Applied Metacognition. Cambridge, UK: Cambridge University Press.

Schoenfeld, A. H. (1992). Learning to think mathematically: Problem solving, metacognition, and sense-making in mathematics.In D. Grouws (Ed.), Handbook for Research on Mathematics Teaching and Learning (pp. 334-370).New York: MacMillan. Tersedia: http://hplengr.engr.wisc.edu/Math_Schoenfeld.pdf

Schraw, G. \& Dennison, R.S. (1994). Assessing metacognitive awareness. Contemporary Educational Psychology, 19, 460-475.

Schraw, G. \& Moshman D. (1995).Metacognitive Theories.Published InEducational Psychology Revie, 7:4, 351-371.

Schunk, Dale H. (2012). Learning Theories: as Education Perspective (Teori-teori Pembelajaran: Perspektif Pendidikan) Edisi keenam. Yogyakarta: Pustaka Pelajar 
Shrawder, Jack H. (2006). Planning a Successful Lesson Publisher/Editor, Teaching For Success South Lake Tahoe, CA jack@teachingforsuccess.com)

Steffe, L. P., Cobb, P., \& Glasersfeld, E. v. (1988). Construction of arithmetic meanings and strategies. New York : Springer-Verlag.

Steffe, L. P., Glasersfeld, E. v., Richards, J., \& Cobb, P. (1983). Children's counting types: Philosophy, theory, and application. New York: Praeger Scientific

TEAL (Teaching Excellence in Adult Literacy). (2012). Just Write! Guide. Washington DC: American Institute for Research (AIR).

Toit, Stephan du. (2009). The Use of Metacognitive Strategies in The Teaching and Learning of Mathematics. Proceedings of the 15th Annual Congress of the Association for Mathematics Education of South Africa (AMESA), 1, 9-21.

Toit, Stephan du; Gawie du Toit. (2013). The Journal for Transdisciplinary Research in Southern Africa, 9(3), Special edition, December 2013, pp. 505-530

Uno, H.B. (2009). Model Pembelajaran Menciptakan Proses Belajar Mengajar yang Kreatif dan Efektif. Jakarta: PT Bumi Aksara.

Veenman, M.V.J., Wilhelm, P., Beishuizen, J.J. (2004).The Relation between Intellectual and Metacognitive Skills from a Developmental Perspective.Learning and Instruction (Elsevier), $14,89-109$.

Voskoglou, Michael Gr. (2008). Problem Solving in Mathematics Education: Recent Trends and Development. Quaderni di Ricerca in Didattica (Scienze Matematiche), 18, 22 - 28, G.R.I.M. (Department of Mathematics, University of Palermo).

Yevdokimov, Oleksiy and Tim Passmore.( 2008). Problem Solving Activities in a Constructivist Framework : Exploring how Students Approach Difficult Problems. Proceedings of the 31st Annual Conference of the Mathematics Education Research Group of Australasia M. Goos, R. Brown, \& K. Makar (Eds.), ( $)$ MERGA Inc. 2008 